\title{
Distribution of the Oxytetracycline Resistance Determinant Tet 34 among Bacteria Isolated from Diseased Fish
}

\author{
LISA NONAKA $^{1}$, TADASHI ISSHIKI ${ }^{2}$ and SATORU SUZUKI*1 \\ ${ }^{1}$ Center for Marine Environmental Studies (CMES), Ehime University, Matsuyama 790-8577, Japan \\ ${ }^{2}$ Kagawa Prefectural Fisheries Experimental Station, Takamatsu, Kagawa 761-0111, Japan
}

(Received September 26, 2001-Accepted December 1, 2001)

The distribution of a newly cloned oxytetracycline (OTC) resistance determinant, Tet 34, was examined among bacterial strains isolated from diseased fish. We analyzed 33 OTC-resistant strains isolated from 1998 to 2000 in Kagawa Prefecture. Tet 34 was detected in 3 of the strains, which were grouped in the genus Vibrio. Minimum inhibitory concentrations (MICs) of the 3 strains were higher than $500 \mu \mathrm{g} / \mathrm{ml}$ in the presence of $\mathrm{MgCl}_{2}$, and 125 or $250 \mu \mathrm{g} / \mathrm{ml}$ in its absence. Tet 34 was found in chromosomal DNA in all positive strains. Polymerase chain reaction (PCR)-denaturing gradient gel electrophoresis of 16S rDNA revealed the 3 strains to have the same migration profiles. The sequences of their PCR products were also identical, suggesting that the species were the same. It was concluded that Tet 34 has been present since at least 1998, and the determinant occurs only in Vibrio species.

Key words: Vibrio, oxytetracycline, resistance, Tet 34, distribution

Antimicrobial drugs such as oxytetracycline (OTC) are widely used in the aquaculture industry to treat fish diseases. Previously, we showed that OTC-resistant bacteria are abundant in the intestines and surroundings of cultured yellowtail (Seriola quinqueradiata) ${ }^{14)}$. We isolated these OTCresistant bacteria and cloned a new OTC resistance determinant, Tet 34, from a strain of Vibrio sp. No. 6 (Antimicrobial Agents and Chemotherapy, in press). This determinant is very similar to the xanthine-guanine phosphoribosyl transferase (XPRT) genes of Vibrio cholerae, suggesting that Tet 34 requires $\mathrm{Mg}^{2+}$. To date, tetracycline (TC) resistance genes, tet $(\mathrm{A})-(\mathrm{E})$, tet $(\mathrm{G})-(\mathrm{K})$, tet $(\mathrm{M})$, tet $(\mathrm{O})$, tet $(\mathrm{Q})$, tet $(\mathrm{W})$, tet $(\mathrm{X})$, tet (30) and tet (31), have been reported in 39 genera of Gram-negative bacteria including marine environmental isolates ${ }^{5)}$.

The Tet series has been reported in a variety of pathogenic and commensal bacteria isolated from humans ${ }^{9,11,13,16)}$,

\footnotetext{
* Corresponding author; E-mail: ssuzuki@agr.ehime-u.ac.jp, Tel: +81-089-927-8552, Fax: +81-089-927-8552

Abbreviations: MIC, minimum inhibitory concentration; TC, tetracycline; OTC, oxytetracycline; BHI, brain heart infusion; PBS, phosphate-buffered saline.
}

$\operatorname{animals}^{1,21)}$, and the environment ${ }^{2,4,6,7,8,16,20)}$, however the distribution of Tet 34 is not known. The objective of the present study is to clarify the distribution of Tet 34 among OTC-resistant, disease-causing bacteria isolated from fish.

\section{Materials and Methods}

\section{Bacterial strains and growth conditions}

OTC-resistant bacteria were isolated from diseased fish (see Table 1) cultured at 14 aquaculture sites in Kagawa Prefecture, Shikoku Island, Japan, (Fig. 1) between 1997 and 2000. Brain heart infusion (BHI) medium supplemented with $1.5 \% \mathrm{NaCl}$ was used to isolate the bacteria. Strains that grew on Thiosulfate Citrate Bile Salts Sucrose (TCBS, Nissui, Tokyo) plates were considered to be of the genus Vibrio. Edwardsiella tarda, Lactococcus garvieae and Photobacterium damsela subsp. piscicida were identified by a slide agglutination test using antisera against each species. As control strains, Vibrio anguillarum V-1037 and Vibrio parahaemolyticus were incubated in Marine broth 2216 (DIFCO, Detroit, MI) or on the solid medium at $25^{\circ} \mathrm{C}$ for 24 h, and Escherichia coli JM 109 was incubated in LB 
Table 1. The OTC-resistant strains used in this study and the results of dot-blot hybridization.

\begin{tabular}{|c|c|c|c|c|c|c|c|c|c|}
\hline \multirow{3}{*}{ Strain } & \multirow{3}{*}{ Origin } & \multirow{3}{*}{ Organ } & \multirow{3}{*}{ Year } & \multirow{3}{*}{ Station $^{\mathrm{a}}$} & \multirow{3}{*}{ Family or species } & \multicolumn{3}{|c|}{ MIC on } & \multirow{3}{*}{$\begin{array}{l}\text { Hybridi- } \\
\text { zation }^{\mathrm{c}}\end{array}$} \\
\hline & & & & & & \multicolumn{2}{|c|}{$\mathrm{NSA}^{\mathrm{b}}$} & \multirow{2}{*}{$\begin{array}{c}\text { BHI with } \\
1.5 \% \\
\mathrm{NaCl}\end{array}$} & \\
\hline & & & & & & $\begin{array}{l}\text { with } \\
\mathrm{Mg}^{2+}\end{array}$ & $\begin{array}{l}\text { without } \\
\mathrm{Mg}^{2+}\end{array}$ & & \\
\hline KIDX-97076 & Striped beakperch & Kidney & 1997 & A & Vibrio sp. & $<62.5$ & $<62.5$ & nd & - \\
\hline KOHX-98043 & Yellowtail & Kidney & 1998 & A & Vibrio sp. & 500 & 250 & nd & - \\
\hline KHOX-98101 & Yellowtail & Kidney & 1998 & A & Vibrio sp. & 500 & 125 & nd & - \\
\hline KTX-98024 & Red sea bream & Liver & 1998 & G & Vibrio sp. & 500 & 125 & nd & + \\
\hline KIDX-98074 & Striped beakperch & Liver & 1998 & A & Vibrio sp. & $<62.5$ & $<62.5$ & nd & - \\
\hline KHRX-98123 & Gold striped amberjack & Kidney & 1998 & G & Vibrio sp. & 500 & 250 & nd & - \\
\hline KFX-98118 & Tiger puffer & Liver & 1998 & $\mathrm{C}$ & Vibrio sp. & 500 & $<62.5$ & nd & - \\
\hline KKAX-99017 & Great amberjack & Liver & 1999 & A & Vibrio sp. & $<62.5$ & $<62.5$ & nd & - \\
\hline KCSX-99104 & Sea bass & Brain & 1999 & A & Vibrio sp. & $<62.5$ & $<62.5$ & nd & - \\
\hline KKUX-99102 & Schlegel's black rockfish & Kidney & 1999 & I & Vibrio sp. & $<62.5$ & $<62.5$ & nd & - \\
\hline KFX-99065 & Tiger puffer & Kidney & 1999 & $\mathrm{C}$ & Vibrio sp. & 250 & 125 & nd & - \\
\hline KHX-00105 & Yellowtail & Brain & 2000 & A & Vibrio sp. & $<62.5$ & $<62.5$ & nd & - \\
\hline KFX-00014 & Tiger puffer & Liver & 2000 & $\mathrm{~K}$ & Vibrio sp. & $<62.5$ & $<62.5$ & nd & - \\
\hline KFX-00019 & Tiger puffer & Kidney & 2000 & $\mathrm{~L}$ & Vibrio sp. & $>500$ & 250 & nd & + \\
\hline KRX-00017 & Japanese flounder & Liver & 2000 & $\mathrm{~K}$ & Vibrio sp. & $>500$ & 250 & nd & + \\
\hline KRE-97013 & Japanese flounder & Kidney & 1997 & $\mathrm{~B}$ & Edwardsiella tarda & nd & nd & 250 & - \\
\hline KRE-97068 & Japanese flounder & Kidney & 1997 & $\mathrm{C}$ & Edwardsiella tarda & nd & nd & 250 & - \\
\hline KRE-97120 & Japanese flounder & Kidney & 1997 & $\mathrm{D}$ & Edwardsiella tarda & nd & nd & $<31.3$ & - \\
\hline KRE-98063 & Japanese flounder & Liver & 1998 & $\mathrm{~B}$ & Edwardsiella tarda & nd & nd & 125 & - \\
\hline KRE-98161 & Japanese flounder & Liver & 1998 & $\mathrm{D}$ & Edwardsiella tarda & nd & nd & $<31.3$ & - \\
\hline KRE-99017 & Japanese flounder & Liver & 1999 & $\mathrm{~J}$ & Edwardsiella tarda & nd & nd & 250 & - \\
\hline KRE-99090 & Japanese flounder & Liver & 1999 & $\mathrm{C}$ & Edwardsiella tarda & nd & nd & 250 & - \\
\hline KRE-99122 & Japanese flounder & Liver & 1999 & $\mathrm{~K}$ & Edwardsiella tarda & nd & nd & 125 & - \\
\hline KRE-00049 & Japanese flounder & Kidney & 2000 & G & Edwardsiella tarda & nd & nd & 250 & - \\
\hline KRE-00115 & Japanese flounder & Kidney & 2000 & $\mathrm{C}$ & Edwardsiella tarda & nd & nd & 250 & - \\
\hline KHS-97051 & Yellowtail & Brain & 1997 & A & Lactococcus garvieae & nd & nd & 250 & - \\
\hline KHS-98032 & Yellowtail & Brain & 1998 & $\mathrm{E}$ & Lactococcus garvieae & nd & nd & 250 & - \\
\hline KHS-98057 & Yellowtail & Brain & 1998 & $\mathrm{~F}$ & Lactococcus garvieae & nd & nd & 250 & - \\
\hline KHS-99008 & Yellowtail & Brain & 1999 & $\mathrm{H}$ & Lactococcus garvieae & nd & nd & 250 & - \\
\hline KHS-99047 & Yellowtail & Brain & 1999 & $\mathrm{C}$ & Lactococcus garvieae & nd & nd & 250 & - \\
\hline KHS-00005 & Yellowtail & Kidney & 2000 & G & Lactococcus garvieae & nd & nd & 250 & - \\
\hline KHS-00083 & Yellowtail & Brain & 2000 & A & Lactococcus garvieae & nd & nd & 250 & - \\
\hline KHOPA-00030 & Yellowtail & Liver & 2000 & $\mathrm{~L}$ & $\begin{array}{l}\text { Photobacterium dam- } \\
\text { sela subsp. piscicida }\end{array}$ & nd & nd & $<31.3$ & - \\
\hline No. 6 & Positive control (origin str & ain of Tet 3 & & & Vibrio sp. & 500 & $<62.5$ & 125 & + \\
\hline V-1037 & Fish origin negative contro & 1 Vibrio $(\mathrm{s}$ & nsitive & o OTC) & Vibrio anguillarum & $<62.5$ & $<62.5$ & $<31.3$ & - \\
\hline V-1070 & Fish origin negative contro & 1 Vibrio $(\mathrm{s}$ & nsitive & o OTC) & Vibrio anguillarum & $<62.5$ & $<62.5$ & $<31.3$ & - \\
\hline V-1109 & Fish origin negative contro & 1 Vibrio $(\mathrm{s}$ & nsitive & o OTC) & Vibrio anguillarum & $<62.5$ & $<62.5$ & $<31.3$ & - \\
\hline V-1212 & Fish origin negative contro & 1 Vibrio $(\mathrm{s}$ & nsitive & o OTC) & Vibrio anguillarum & $<62.5$ & $<62.5$ & $<31.3$ & - \\
\hline ATCC $17802 \mathrm{~T}$ & Non-fish strain negative co & ntrol (sen & itive to & DTC) & Vibrio parahaemolyticus & $<62.5$ & ng & $<31.3$ & - \\
\hline NCMB1903T & Non-fish strain negative co & ntrol (sen & itive to & OTC) & Vibrio alginolyticus & $<62.5$ & $<62.5$ & $<31.3$ & - \\
\hline
\end{tabular}

nd, not done. ng, did not grow.

${ }^{\mathrm{a}}$ see Fig. 1.

${ }^{\mathrm{b}}$ Nutrient salt agar.

${ }^{\mathrm{c}}+$, positive; - , negative. 


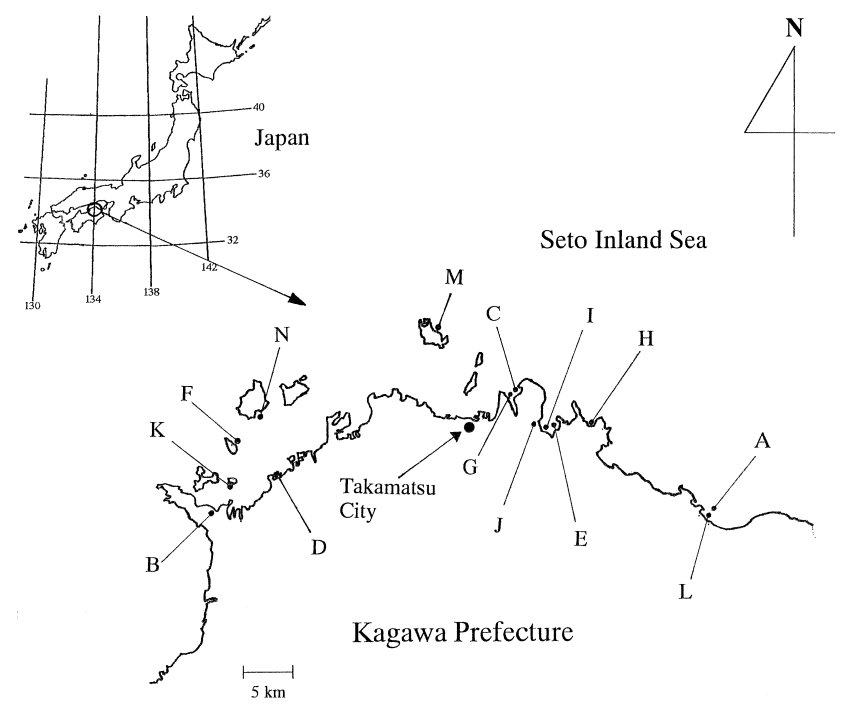

Fig. 1. Location of sampling sites in Kagawa Prefecture, Shikoku Island, Japan.

broth (DIFCO) at $37^{\circ} \mathrm{C}$ for $12 \mathrm{~h}$.

\section{Screening for OTC resistance}

To detect OTC-resistant strains, the following screening was performed. Filter disks containing $30 \mu \mathrm{g} / \mathrm{ml}$ of OTC were placed on agar plates spread with each strain and incubated at $25^{\circ} \mathrm{C}$. After $16-18 \mathrm{~h}$, the diameters of the inhibition halos that formed surrounding the filter disks were measured. If the diameter of the halo was greater than $25 \mathrm{~mm}$, the bacteria were considered to be resistant to OTC. A total of 33 OTC-resistant strains were detected, including 15 strains of Vibrio, 10 strains of E. tarda, 7 strains of $L$. garvieae and 1 strain of $P$. damsela subsp. piscicida (Table 1).

\section{Minimum inhibitory concentration (MIC)}

The MICs of the OTC-resistant strains were measured as follows. Nutrient salt agar (NSA) plates containing $5 \mathrm{~g}$ of polypeptone (Wako, Osaka), $20 \mathrm{~g}$ of $\mathrm{NaCl}$ per liter of distilled water, and $1 \mathrm{~g}$ each of yeast extract (DIFCO), proteose peptone (DIFCO), and beef extract (Wako, Osaka) were used for Vibrio sp. To test whether $\mathrm{Mg}^{2+}$ was needed for OTC resistance, nutrient salt broths with and without 10 $\mathrm{mM} \mathrm{MgCl}{ }_{2}$ were used. BHI agar plates supplemented with $1.5 \% \mathrm{NaCl}$ were used to determine the MICs of E. tarda, $L$. garvieae and $P$. damsela subsp. piscicida. A cell suspension was prepared in phosphate-buffered saline (PBS), and the cell density was adjusted to MacFaland No. 0.5. The suspensions were spotted on agar plates containing 62.5, 125, 250 and $500 \mu \mathrm{g} \mathrm{OTC} / \mathrm{ml}$ for Vibrio sp. For the other strains, the agar plates contained $31.3,62.5,125,250$ and $500 \mu \mathrm{g}$ $\mathrm{OTC} / \mathrm{ml}$. The plates were incubated at $25^{\circ} \mathrm{C}$ or $30^{\circ} \mathrm{C}$ for 24 $\mathrm{h}$, and the lowest concentration needed for inhibition was recorded.

\section{Chromosomal and plasmid DNA extraction}

Genomic DNA was extracted from the OTC-resistant strains and control strains as follows. First, a bacterial cell pellet was suspended in an extraction solution $(0.15 \mathrm{M}$ $\mathrm{NaCl}, 0.1 \mathrm{M}$ EDTA, $0.5 \mathrm{mg} / \mathrm{ml}$ RNase A and 0.5\% SDS) and incubated at $65^{\circ} \mathrm{C}$ for $5 \mathrm{~min}$. The DNA was purified by extraction with phenol saturated with TE buffer $[10 \mathrm{mM}$ Tris- $\mathrm{HCl}(\mathrm{pH} 8.0)$ and $1 \mathrm{mM}$ EDTA]. It was further extracted two times with a TE-saturated phenol:chloroform: iso-amyl alcohol (25:24:1, v/v/v) solution, and one time with chloroform. The DNA was finally precipitated using ethanol. Plasmid extraction was performed according to the method of Sambrook et al. ${ }^{19)}$. Purified chromosomal and plasmid DNA was resuspended in $50 \mu \mathrm{l}$ of TE and stored at $-20^{\circ} \mathrm{C}$.

\section{Dot-blot and Southern hybridization}

To examine the distribution of Tet 34 (DDBJ accession number; AB061440) among the OTC-resistant strains, dotblot hybridization was performed. A $2-\mu \mathrm{g}$ portion of the chromosomal and plasmid DNA of the OTC-resistant strains was incubated at $95^{\circ} \mathrm{C}$ for $5 \mathrm{~min}$, and then the same volume of $20 \times \mathrm{SSC}$ was added to the solution. This solution was directly applied onto a nylon membrane using a BioRad Bio-Dot SF microfiltration apparatus (Bio-Rad Laboratories, Hercules, CA). The blotted filters were then denatured by treatment with a solution containing $0.5 \mathrm{~N} \mathrm{NaOH}$ and $1.5 \mathrm{M} \mathrm{NaCl}$, and neutralized with a solution containing $0.5 \mathrm{M}$ Tris- $\mathrm{HCl}(\mathrm{pH} 7.2), 1.5 \mathrm{M} \mathrm{NaCl}$ and $1 \mathrm{mM}$ EDTA. The DNA was fixed with UV-light $(254 \mathrm{~nm})$ irradiation for $1 \mathrm{~min}$. The blotted filters were prehybridized with $5 \mathrm{ml}$ of warmed hybridization buffer $\left[0.5 \mathrm{M} \mathrm{NaH} \mathrm{PO}_{4}, 1 \mathrm{mM}\right.$ EDTA and 7\% SDS (pH 7.2)] in a heat-sealing bag at $65^{\circ} \mathrm{C}$ for $5 \mathrm{~min}$. The Tet 34 fragment cleaved out from the plasmid pOV, which was constructed by the ligation of Tet 34 into pUC119, was labeled with the DIG-Chem-Link Labeling and Detection Set (Roche Diagnostics, Mannheim, Germany) in accordance with the manufacturer's directions. The labeled DNA probe was denatured by heating at $95^{\circ} \mathrm{C}$ for $10 \mathrm{~min}$ and rapidly cooled on ice before use for hybridization. A 50-ng aliquot of the digoxigenin-labeled DNA probe was added to the solution, and hybridization was performed at $65^{\circ} \mathrm{C}$ overnight with shaking. After the hybridization, the membrane was washed three times with washing 
solution (40 mM NaH $\mathrm{PO}_{4}$ and $0.1 \%$ SDS, pH 7.2) for 5 min each. The digoxigenin-labeled DNA was reacted with nitroblue tetrazolium chloride/ 9-bromo-4-chloro-3-indoyl phosphate toluidine salt (NBT/BCIP), followed by an antidigoxigenin, antibody-conjugated, alkaline phosphatase (Roche Diagnostics, Mannheim, Germany).

To determine whether Tet 34 was located on chromosomal or plasmid DNA, Southern blot hybridization was performed. A 10- $\mu \mathrm{g}$ aliquot of chromosomal or plasmid DNA was digested with the endonucleases $P s t$ I (TaKaRa, Japan) and EcoR I (TaKaRa, Japan), separated on a $0.8 \%$ agarose gel, and briefly depurinated with $0.25 \mathrm{~N} \mathrm{HCl}$. Denaturation was performed by treatment with a solution containing 0.5 $\mathrm{N} \mathrm{NaOH}$ and $1.5 \mathrm{M} \mathrm{NaCl}$, and then neutralized with a solution containing $0.5 \mathrm{M}$ Tris- $\mathrm{HCl}(\mathrm{pH} 7.2), 1.5 \mathrm{M} \mathrm{NaCl}$ and 1 mM EDTA. The DNA was then transferred to a positively charged nylon membrane (Hybond N+, Amersham, Buckinghamshire, UK) by upward capillary transfer using $20 \times \mathrm{SSC}$ for $16-20 \mathrm{~h}$, and fixed with UV-light $(254 \mathrm{~nm}$ ) irradiation for $1 \mathrm{~min}$. The methods used for hybridization with the Tet 34 probe and detection were the same as described above.

\section{Polymerase chain reaction (PCR)-denaturing gradient gel electrophoresis (DGGE)}

DGGE can identify a single point mutation on a gene, so it can be used to separate bacterial species based on the $16 \mathrm{~S}$ rDNA sequence ${ }^{12)}$. To examine whether the Tet 34-positive strains were of the same species or not, 16S rDNA-targeted PCR was performed and the products were analyzed by DGGE. The V6, 7, 8 region of $16 \mathrm{~S}$ rDNA was amplified with universal primers for the conserved region of the $16 \mathrm{~S}$ rRNA $^{10}$. The PCR product was $455 \mathrm{bp}$, corresponding to the position from 933 to 1387 (E. coli numbering). A hot start and touch down PCR was performed according to a previous report ${ }^{10}$. The PCR products were analyzed on $8 \%$ polyacrylamide gels with urea-formamide gradients of 40 to $70 \%$. Electrophoresis was performed at $10 \mathrm{~V}$ for $10 \mathrm{~min}$ and then at $200 \mathrm{~V}$ for $4 \mathrm{~h}$ at $55^{\circ} \mathrm{C}$ using the DCode System (BioRad Laboratories, Hercules, CA). After electrophoresis, the gels were stained with ethidium bromide solution and visualized under UV light. The PCR products run on the DGGE gel were sequenced using an ABI PRISM BigDye Terminator Cycle Sequencing FS Ready Reaction Kit (PE Biosystems, Tokyo) and ABI PRISM 310 DNA sequencer (PE Biosystems, Tokyo) at the Center for Gene Research, Ehime University.

\section{Results and Discussion}

A total of 33 strains of OTC-resistant bacteria were isolated from diseased fish between 1997 and 2000. Three strains (KTX-98024, KFX-00019 and KRX-00017) of the genus Vibrio were determined to be Tet 34-positive based on dot-blot hybridization (Table 1). KTX-98024 was isolated in 1998 and the other 2 strains in 2000, suggesting that Tet 34-carrying bacteria have occurred since at least 1998. The other Vibrio sp. strains and all strains of E. tarda, $L$. garvieae and $P$. damsela subsp. piscicida were negative for Tet 34. We isolated Vibrio sp. harboring Tet 34 from the intestinal contents of apparently healthy yellowtail in 1999 (unpublished data). Thus, OTC-resistant bacteria possessing Tet 34 are thought to be ubiquitous in cultured fish and their environment. The administration of OTC might apply a selective pressure on the bacteria having Tet 34 in cultured fish.

The Tet 34-positive strains (KTX-98024, KFX-00019 and KRX-00017) showed MICs of $\geq 500 \mu \mathrm{g} / \mathrm{ml}$ in the presence of $\mathrm{Mg}^{2+}$. These MICs were two-fold greater than those without $\mathrm{MgCl}_{2}$. The resistance of the Vibrio sp. No. 6 conferred by Tet 34 increases in the presence of $\mathrm{MgCl}_{2}$ (Table 1). The results of the present study confirm that the resistance caused by Tet 34 is $\mathrm{Mg}^{2+}$-dependent. Known TC-resistant mechanisms include efflux systems and ribosomal protection. All efflux genes [tet (A), tet (C), tet $(\mathrm{D})$, tet $(\mathrm{E})$, tet $(\mathrm{G})$ and tet $(\mathrm{H})$ and probably tet $(\mathrm{I})]$ need $\mathrm{Mg}^{2+5)}$. Therefore, the resistant strains without Tet 34 may become OTC-resistant by known $\mathrm{Mg}^{2+}$-dependent mechanisms.

To examine the location of Tet 34, Southern hybridization was performed for the positive strains. KTX-98024, KFX-00019 and KRX-00017 possessed several plasmids, and the plasmid profiles differed among the strains (Fig. 2). We could not clearly show whether the chromosomal DNA preparation contains mega plasmid DNA, because the plasmid extraction method used in this study was for the small plasmid not for the mega plasmid. A positive signal was detected in the chromosomal DNA at approximately $1 \mathrm{kbp}$ (Fig. 3) but not in the plasmid DNA, and the distribution was restricted in the Vibrio species, suggesting that Tet 34 was not associated with mobile elements. Most tet genes are associated with mobile plasmids, transposons, conjugative transposons and integrons ${ }^{15,17,18}$. These mobile elements allow the tet genes to move to other species. Scott $e t$ al. $\left.{ }^{22}\right)$ reported that a transmissible TC resistance element was found in the chromosomal DNA of an obligatory anaerobic rumen bacterium. Moreover, tet $(\mathrm{G})$ discovered in the fish patho- 


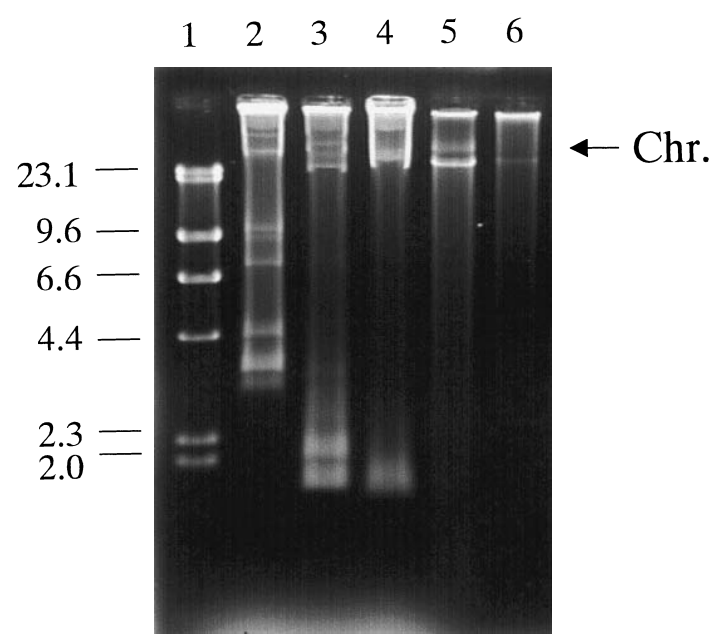

Fig. 2. Plasmid profiles of the Vibrio spp. possessing Tet 34. Lane 1, size maker (kbp); lane 2, Vibrio sp. KTX-98024; lane 3, Vibrio sp. KFX-00019; lane 4, Vibrio sp. KRX-00017; lane 5, Vibrio sp. No. 6 and lane 6, E. coli JM 109 as a plasmid-free control. Chr. indicates chromosome.

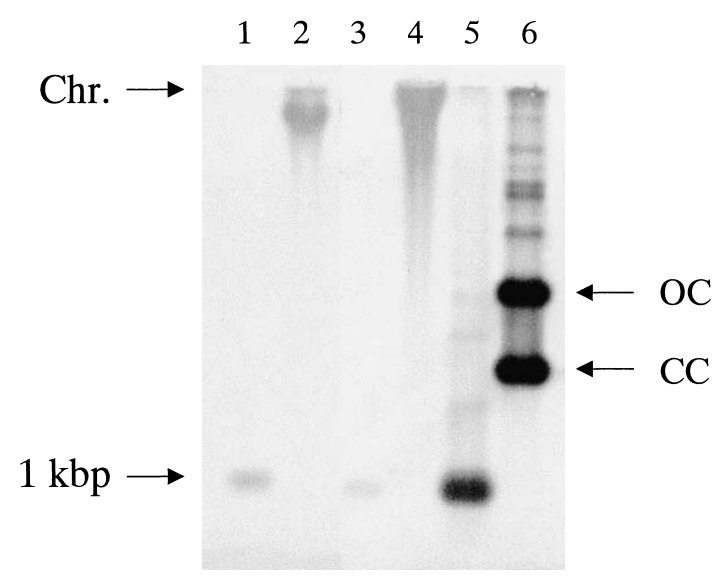

Fig. 3. Southern hybridization analysis of chromosomal DNA extracted from OTC-resistant Vibrio spp. Lane 1, DNA of KTX-98024 digested with Pst I and EcoR I; lane 2, DNA of KTX-98024; lane 3, DNA of Vibrio sp. No. 6 digested with Pst I and EcoR I; lane 4, DNA of Vibrio sp. No. 6; lane 5, pOV digested with Pst I and EcoR I and lane 6, non-digested pOV. The hybridization probe was the cloned Tet 34 . Chr. and $1 \mathrm{kbp}$ at the left indicate chromosome and the size of the positive band, respectively. $\mathrm{OC}$ and $\mathrm{CC}$ at the right indicate open circular and closed circular plasmid pOV, respectively.

gen Vibrio anguillarum ${ }^{3,23)}$ was found in 10 human and 8 non-human isolates other than Vibrio ${ }^{13)}$. This suggests that tet $(\mathrm{G})$ is widely distributed in both aquatic and human environments. Rhodes et al. ${ }^{16)}$ reported that a TC resistanceencoding plasmid was disseminated between different

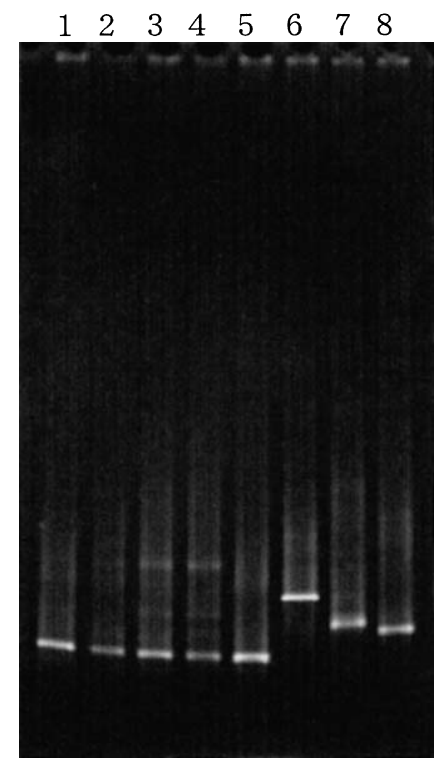

Fig. 4. Profile of DGGE analysis of $16 \mathrm{~S}$ rDNA amplicons from OTC-resistant strains of Vibrio spp. carrying Tet 34. Lanes 1 and 5, Vibrio sp. No. 6 used as a positive control; Lanes 2 to 4, OTCresistant Vibrio sp. strains KTX-98024, KFX-00019 and KRX00017, respectively. Lane 6, Vibrio anguillarum V-1037; lane 7, Vibrio parahaemolyticus ATCC $17802 \mathrm{~T}$ and lane 8, Escherichia coli JM 109.

Aeromonas species and E. coli that occur in distinct human and aquaculture environments. Further study is needed to determine how Tet 34 is transferred among bacterial communities.

A DGGE profile is shown in Fig. 4. The PCR products of the strains KTX-98024, KFX-00019, and KRX-00017, and of Vibrio sp. No. 6 showed the same migration profiles. This indicates that the strains had the same $16 \mathrm{~S}$ rDNA sequence and suggests a very close genetic relation. Furthermore, the sequence of the PCR products of these three strains showed $100 \%$ identify, which confirmed that these strains were the same. Tet $(\mathrm{K})$, tet $(\mathrm{M})$, tet $(\mathrm{O})$, tet $(\mathrm{Q})$ and tet $(\mathrm{W})$ occur among numerous Gram-negative bacterial genera, whereas tet $(\mathrm{H})$, tet $(\mathrm{I})$, tet $(\mathrm{J})$, tet $(\mathrm{Y})$, tet $(30)$ and tet (31) are carried by a restricted $\mathrm{few}^{5}$. Our results suggest that Tet 34 occurs only in Vibrio species, although further work is required to determine all the hosts. It is worth noting that the 3 species that tested positive for Tet 34 were isolated from diseased fish in 1998 and 2000, whereas the original strain, Vibrio sp. No. 6, was isolated from an apparently healthy yellowtail in 1999. This suggests that KTX-98024, KFX-00019, KRX-00017 and Vibrio sp. No. 6 may be opportunistic fish pathogens in that they occur normally in host fish but cause disease under certain conditions. 
Animals, plants and various environments may contain such opportunists acting not only as pathogens, but as reservoirs of antibiotic resistance genes ${ }^{2}$. In the future, we plan to examine the distribution and transferability of Tet 34 to clarify its dynamics in the marine environment.

\section{Acknowledgements}

We thank Dr. John Bower, Hokkaido University, for his critical review of this manuscript, and Dr. Shin-ichi Nakano in our laboratory for his useful suggestions. This work was partly supported by a Grant-in-Aid from the Ministry of Education, Science, Sports, Culture and Technology, Japan. Genetic experiments in this study were performed in the Center for Gene Research, Ehime University.

\section{References}

1) Aminov, R.I., N. Garrigues-Jeanjean and R.I. Mackie. 2001 Molecular ecology of tetracycline resistance: development and validation of primers for detection of tetracycline resistance genes encoding ribosomal protection proteins. Appl. Environ. Microbiol. 67: 22-32.

2) Andersen, S.R. and R.-A. Sandaa. 1994. Distribution of tetracycline resistance determinants among Gram-positive bacteria isolated from polluted and unpolluted marine sediments. Appl. Environ. Microbiol. 60: 908-912.

3) Aoki, T., T. Satoh and T. Kitao. 1987. New tetracycline resistance determinant on R plasmid from Vibrio anguillarum. Antimicrob. Agents Chemother. 31: 1446-1449.

4) Chee-Sanford, J.C., R.I. Aminov, I.J. Krapac, N. GarriguesJeanjean and R.I. Mackie. 2001. Occurrence and diversity of tetracycline resistance genes in lagoons and groundwater underlying two swine production facilities. Appl. Environ. Microbiol. 67: 1494-1502.

5) Chopra, I. and M. Roberts. 2001. Tetracycline antibiotics: mode of action, applications, molecular biology, and epidemiology of bacterial resistance. Microbiol. Mol. Biol. Rev. 65: 232-260.

6) Depaola, A. and M.C. Roberts. 1995. Class D and E tetracycline determinants in Gram-negative bacteria from catfish ponds. Mol. Cell. Probes 9: 311-313.

7) DePaola, A., P.A. Flynn, R.M. McPhearson and S.B. Levy. 1988. Phenotypic and genotypic characterization of tetracycline- and oxytetracycline-resistant Aeromonas hydrophila from cultured channel catfish (Ictalurus punctatus) and their environments. Appl. Environ. Microbiol. 54: 1861-1863.

8) DePaola, A., W.E. Hill and F.M. Harrell. 1993. Oligonucleotide probe determination of tetracycline-resistant bacteria isolated from catfish ponds. Mol. Cell. Probes 7: 345-348.
9) Guardabassi, L., L. Dijkshoorn, J.-M. Collard, J.E. Olsen and A. Dalsgaard. 2000. Distribution and in-vitro transfer of tetracycline resistance determinants in clinical and aquatic Acinetobacter strains. J. Med. Microbiol. 49: 929-936.

10) Iwamoto, T., K. Tani, K. Nakamura, Y. Susuki, M. Kitagawa, M. Eguchi and M. Nasu. 2000. Monitoring impact of in situ biostimulation treatment on groundwater bacterial community by DGGE. FEMS Microbiol. Ecol. 32: 1-13.

11) Leng, Z., D.E. Riley, R.E. Berger, J.N. Krieger and M.C. Roberts. 1997. Distribution and mobility of the tetracycline resistance determinant tet Q. J. Antimicrob. Chemother. 40: 551-559.

12) Muyzer, G., E.C.D. Wall and A.G. Uitterlinden. 1993. Profiling of complex microbial populations by denaturing gel electrophoresis analysis of polymerase chain reaction-amplified genes coding for 16S rRNA. Appl. Environ. Microbiol. 59: 695-700.

13) Ng, L.-K., M.R. Mulvey, I. Martin, G.A. Peters and W. Johnson. 1999. Genetic characterization of antibiotic resistance in Canadian isolates of Salmonella serovar typhimurium DT104. Antimicrob. Agents Chemother. 43: 3018-3021.

14) Nonaka, L., T. Isshiki and S. Suzuki. 2000. The occurrence of the oxytetracycline resistant bacteria in the fish intestine and seawater environment. Microb. Environ. 15: 223-228.

15) Rechia, G.D. and R.M. Hall. 1995. Gene cassettes: anew class of mobile element. Microbiology 141: 3015-3027.

16) Rhodes, G., G. Huys, J. Swings, P. McGann, M. Hiney, P. Smith and R.W. Pickup. 2000. Distribution of oxytetracycline resistance plasmids between Aeromonads in hospital and aquaculture environments: implication of Tn 1721 in dissemination of the tetracycline resistance determinant Tet A. Appl. Environ. Microbiol. 66: 3883-3890.

17) Roberts, M.C. 1994. Epidemiology of tetracycline-resistance determinants. Trends Microbiol. 10: 353-357.

18) Roberts, M.C. 1996. Tetracycline resistance determinants: mechanisms of action, regulation of expression, genetic mobility, and distribution. FEMS Microbiol. Rev. 19: 1-24.

19) Sambrook, J. and D.W. Russell. 2000. Molecular cloning: a laboratory manual, 3rd ed. Cold Spring Harbor Laboratory Press, Cold Spring Harbor, N.Y.

20) Schnabel, E.L. and A.L. Jones. 1999. Distribution of tetracycline resistance genes and transposons among phylloplane bacteria in Michigan apple orchards. Appl. Environ. Microbiol. 65: 48984907.

21) Schwarz, S., M.C. Roberts, C. Werckenthin, Y. Pang and C. Lange. 1998. Tetracycline resistance in Staphylococcus spp. from domestic animals. Vet. Microbiol. 63: 217-227.

22) Scott, K.P., T.M. Barbosa, K.J. Forbes and H.J. Flint. 1997. Highfrequency of a naturally occurring chromosomal tetracycline resistance element in the ruminal anaerobe Butyrivibrio brisolvens. Appl. Environ. Microbiol. 63: 3405-3411.

23) Zhao, J. and T. Aoki. 1992. Nucleotide sequence analysis of the class $\mathrm{G}$ tetracycline resistance determinant from Vibrio anguillarum. Microbiol. Immnol. 10: 1051-1060. 